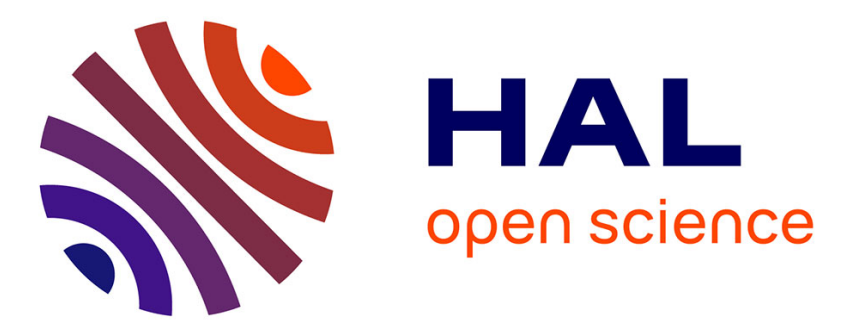

\title{
Spatial heterogeneity of land cover response to climatic change in the Nilgiri highlands (southern India) since the Last Glacial Maximum
}

Laurent Caner, Danny Lo Seen, Yanni Gunnell, B. R. Ramesh, G. Bourgeon

\section{- To cite this version:}

Laurent Caner, Danny Lo Seen, Yanni Gunnell, B. R. Ramesh, G. Bourgeon. Spatial heterogeneity of land cover response to climatic change in the Nilgiri highlands (southern India) since the Last Glacial Maximum. The Holocene, 2007, 17, pp.195-205. 10.1177/0959683607075833 . hal-00255867

\section{HAL Id: hal-00255867 \\ https://hal.science/hal-00255867}

Submitted on 14 Feb 2008

HAL is a multi-disciplinary open access archive for the deposit and dissemination of scientific research documents, whether they are published or not. The documents may come from teaching and research institutions in France or abroad, or from public or private research centers.
L'archive ouverte pluridisciplinaire $\mathbf{H A L}$, est destinée au dépôt et à la diffusion de documents scientifiques de niveau recherche, publiés ou non, émanant des établissements d'enseignement et de recherche français ou étrangers, des laboratoires publics ou privés. 


\title{
Spatial heterogeneity of land cover response to climatic change in the Nilgiri highlands (southern India) since the Last Glacial Maximum
}

\author{
CANER Laurent, Lo SEEN Danny, GUNNELL Yanni, RAMESH B. R. and \\ BOURGEON Gérard
}

\section{Accepted Version: The Holocene Research Paper, 2007, 17, 195-205}

\section{Addresses:}

Laurent Caner. Université de Poitiers, UMR 6532 HYDRASA, Bâtiment des Sciences Naturelles, 40, Avenue du Recteur Pineau, 86022 Poitiers - France. E-mail: laurent.caner@univpoitiers. fr. Phone: +33 (0)5 49453670 - Fax: +33 (0)5 49454241 .

Danny Lo Seen. CIRAD, UPR Spatialisation, Maison de la Télédétection, 500 rue Jean-François Breton, TA 40/MTD 34398 Montpellier cedex 5 - France. E-mail: danny.loseen@cirad.fr. Phone: +33 (0)4 67548736 . Fax: +33(0)4 67548700

Yanni Gunnell. Department of Geography, Université Denis-Diderot Paris 7, CNRS UMR 8591, case courrier 7001, 2 Place Jussieu, 75251 Paris cedex 05 - France. E-mail: gunnell@idf.ext.jussieu.fr. Phone/Fax: + 33 (0)1 40961301

B.R. Ramesh. French Institute of Pondicherry, 11, Saint Louis Street, P.B. 33, Pondicherry 605 001 - India. E-mail: ramesh.br@ifpindia.org. Phone: +91 413 2334168. Fax: +91 4132339534

Gérard Bourgeon. CIRAD, UPR Recyclage et risque, Avenue Agropolis, Montpellier F - 34398 France. E-mail: bourgeon@cirad.fr. Phone: +33 (0)4 676171 86. Fax: +33 (0)4 67615642. 


\begin{abstract}
Fourteen hillslope soil profiles were sampled under natural vegetation (i.e., grassland or forest) and plantations in the Nilgiri highlands, southern India. Delta ${ }^{13} \mathrm{C}$ ratios were measured at different depths and ${ }^{14} \mathrm{C}$ ages determined for six profiles. In these highland soils where the turnover rate of organic matter is extremely low, the $\delta^{13} \mathrm{C}$ ratios of entire soil profiles have recorded signatures of past land cover. By correlating the data with results previously obtained from peat bogs and with knowledge concerning the history of human settlement, we distinguish three contrasting trajectories of palaeoenvironmental history and landscape change since the Last Glacial Maximum. In the central Nilgiris, between 18 and $10 \mathrm{ka} \mathrm{BP}$, forest expansion occurred due to the conjunction of a wetter climate (the maximum of southwest monsoon-related humidity occurring at ca. $11 \mathrm{ka}$ $\mathrm{BP}$ ) and higher temperatures; since $10 \mathrm{ka}$ BP, the reversal towards grassland vegetation is attributed to drier conditions. In the western Nilgiris, where strong southwest monsoon winds permanently restrict forest patches to sheltered valley sites, steady but limited expansion of forest from $18 \mathrm{ka} \mathrm{BP}$ to the present is recorded and attributed to rising temperatures. The southern and eastern Nilgiris, where the northeast monsoon contributes $20 \%$ of the annual rainfall, are the less sensitive to fluctuations in the southwest monsoon. In these areas, rapid and extensive expansion of forest occurred mainly as a consequence of higher temperatures from $18 \mathrm{ka} \mathrm{BP}$ to the present. Massive deforestation by Badaga cultivators and Europeans planters followed after the 16th century $\mathrm{AD}$. As a result, and in contrast with the western Nilgiris where the land cover mosaic has remained remarkably stable in the last $18 \mathrm{ka} \mathrm{BP}$, the current landscape differs sharply from the land cover pattern detected by the soil record.
\end{abstract}

Keywords : India, soil organic matter, carbon isotope ratios, Asian monsoon, land cover, Late Glacial Maximum.

\title{
Introduction
}

Despite their limited surface area, the highlands of southern India (i.e., Nilgiri, Palni and Anamalai Hills) are situated within the Western Ghats and Sri Lanka biodiversity hotspot (Myers et al., 2000) and have long attracted the attention of naturalists. The exceptional value of the Nilgiri 
ecosystems was officially acknowledged by the creation of the Nilgiri Biosphere Reserve by the Indian authorities in 1986, later approved by the Man And Biosphere (MAB) programme of UNESCO in 2000. Today, the western ranges of the Nilgiri plateau (Figure 1), including the extensive grasslands (Figure 2), are almost entirely classified as Reserved Forests (RF). The Nilgiri highlands have also long been an oasis for palaeoenvironmental research within an otherwise unrewarding South Indian craton in terms of Quaternary environmental archives. The main attraction in this high-rainfall region has been the peat bogs, which have afforded historical insights into the debate among ecologists concerning the origin of the grassland patches, and specifically whether these were natural or generated by human disturbance (Legris, 1963, pp. 219-221). This debate echoes wider controversies in tropical ecology over the origin of savannas. Climatic, paleoclimatic, edaphic and human factors have been considered responsible for the presence of savanna vegetation. The most common assumption (but potentially mistaken: see a critique in Fairhead and Leach, 1998) in the case of forest-savanna mosaics has been that savannas resulted from the degradation by humans of a pre-existing forest continuum (Aubréville, 1947). However, modern tools of palaeoecological investigation, e.g., palynology and stable isotope analyses of peat cores, have established that Nilgiri grasslands had been even more extensive in the past (particularly during the Last Glacial Maximum: LGM, 20-18 ka BP) than at the present time (Sukumar et al., 1993, 1995). This cannot be interpreted as a consequence of human land clearance.

The uptake of carbon isotopes by plants during photosynthesis involves fractionation between ${ }^{13} \mathrm{C}$ and ${ }^{12} \mathrm{C}$. Discrimination against ${ }^{13} \mathrm{C}$ is higher for $\mathrm{C}_{3}$ plants that use the Calvin cycle (woody plants and temperate grasses) than for $\mathrm{C}_{4}$ plants that follow the Hatch-Slack cycle (most of the tropical grasses). The $\mathrm{C}_{4}$ pathway is designed to minimize losses to photorespiration, and the detection of $\mathrm{C}_{4}$ plants in soil or sedimentary archives therefore reflects palaeoenvironments in which vegetation was adjusted to thermal and/or moisture stresses. Fractionation of carbon isotopes also subsequently occurs during the mineralization of soil organic matter (SOM), but $\delta^{13} \mathrm{C}$ can be used as a tool to reconstruct shifting vegetation mosaics through space and time (Balesdent et al., 1987, Boutton et al., 1998). This method has been used by several authors to reconstruct changes in the boundaries between forest and savanna ecosystems in the tropics (Guillet et al., 1988; Mariotti and Peterschmidt, 1994; Desjardin et al., 1996; Schwartz et al., 1996; Pessenda et al., 


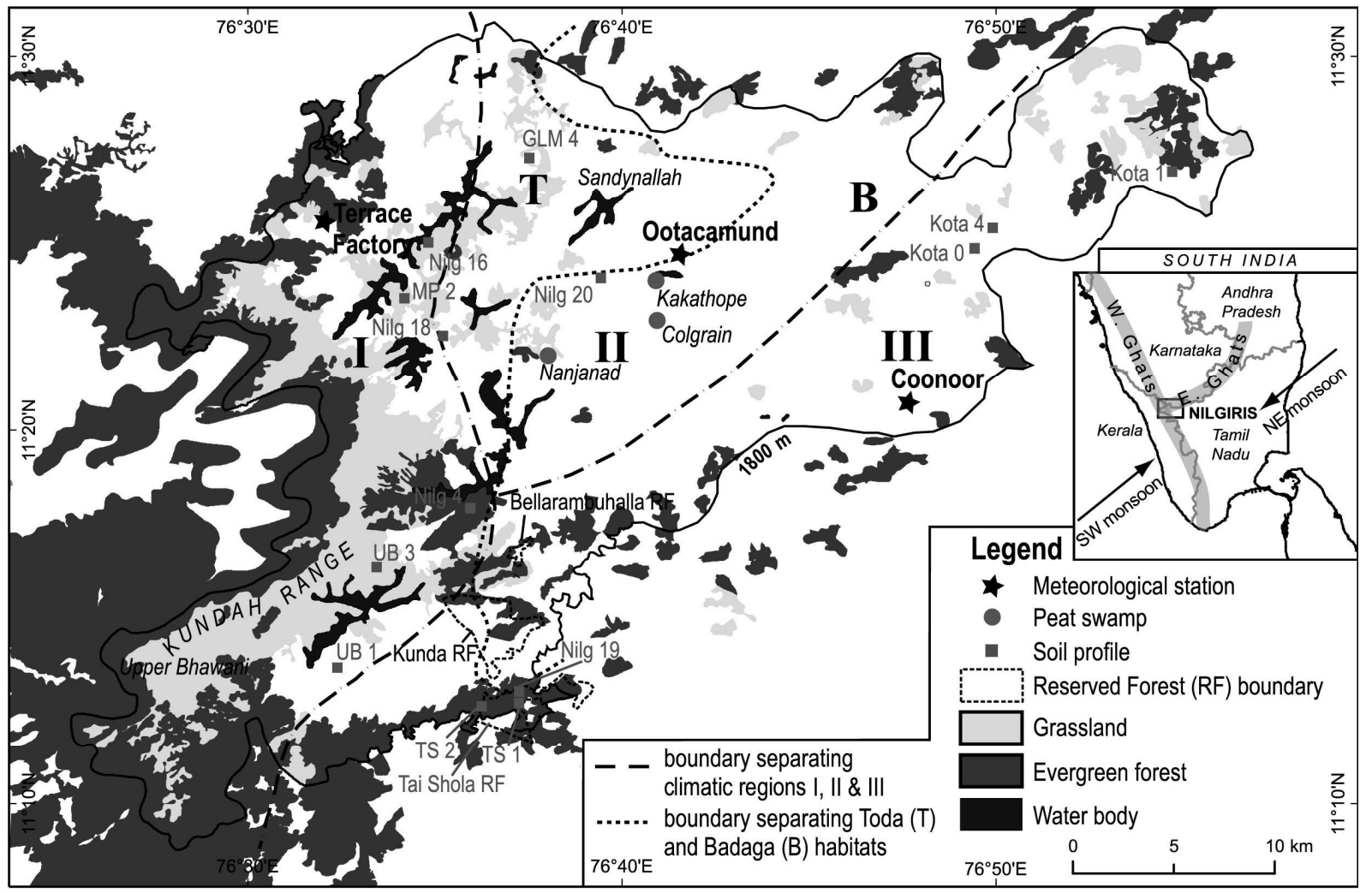

Figure 1. Study area and location of analysed soil profiles. Location of peat bogs, three main climatic regions (I, II, III), areas corresponding to pre-European territorial settlement (Toda and Bagada communities), and place names used in the text are also shown. Forest and grassland limits redrawn from Ramesh et al. (2002). For sake of clarity, land cover types other than grasslands and evergreen forests have been omitted. They otherwise include mainly tea plantations and wattle

1998, 2001, Freitas et al., 2001; Bowman et al., 2004). Following these authors, and particularly Sukumar et al. (1993) for the Nilgiris, we interpret $\mathrm{C}_{4}$-type plant signals as grassland signatures and $\mathrm{C}_{3}$-type plants signals as forest signatures, keeping in mind that some grasses growing under moist conditions have a $\mathrm{C}_{3}$ pathway of photosynthesis and can also spread when the monsoon intensifies (e.g., some Cypereae and Areraceae species: Rajagopalan et al., 1999). Variation of $\delta^{13} \mathrm{C}$ down soil profiles provides an indication of the relative contribution of $\mathrm{C}_{3}$ versus $\mathrm{C}_{4}$ plants through time. Sukumar et al. $(1993,1995)$ analysed data from five peat bogs and defined three time slices in the vegetation history of the Nilgiris: (1) from 20 to $18 \mathrm{ka} \mathrm{BP}$, a dominance of grassland $\left(\mathrm{C}_{4}\right)$ plants was explained by relatively low rainfall and lower temperatures. (2) From 
(a)

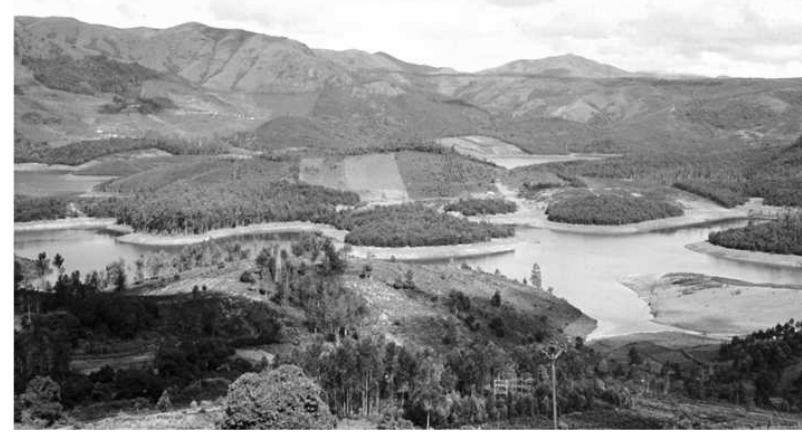

(b)

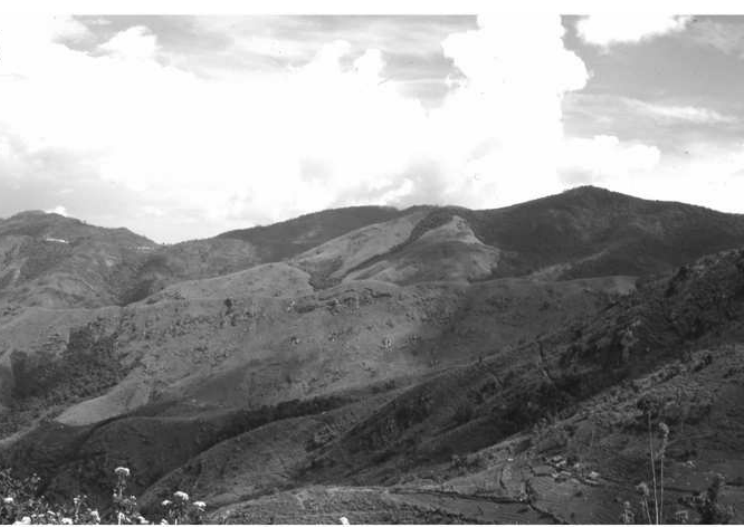

Figure 2 The land-cover mosaic of the Nilgiris. Elevations range between $c a$. 2000 (lake level) and 2500 m a.s.1. (rounded crests). Photograph (a) shows the Emerald Reservoir (close to Nilg 4 in region II). The western ranges (region I) correspond to the crests and slopes in the background. Region II corresponds to the low hills of the foreground surrounding the lake, with numerous tree plantations. Photograph (b) is a closer view of the western ranges, with forest located in the valleys and grassland covering slopes and rounded crests.

18 to $10 \mathrm{ka} \mathrm{BP}$, the expansion of $\mathrm{C}_{3}$ plants (forests or $\mathrm{C}_{3}$ grasslands) was attributed to a more humid climate and higher temperatures. This is consistent with the known maximum of monsoonrelated humidity in South Asia after the LGM, which was recorded at ca. 11 ka BP (Wasson, 1995) (3) From $10 \mathrm{ka}$ BP to the present, a general trend towards $\mathrm{C}_{4}$ vegetation was attributed to a drier climate with a short, wetter event around 900 a BP tentatively correlated to the Medieval Warm Period (see also Rajagopalan et al., 1997).

The use of valley peat records to reconstruct palaeoenvironmental variation is standard practice in many settings, but one disadvantage, particularly in hilly terrain, is that it is susceptible to bias towards riparian or footslope (i.e., local) vegetation. The advantage of conjunctively interrogating the soil record of palaeoenvironmental change is that hillslopes and hilltops, which may have distinct ecological histories from valleys due to factors of elevation and exposure, can yield unexpected dividends for monitoring the finer detail of landscape evolution.

This regional study is the first to use carbon isotopes in SOM to infer long-term vegetation dynamics in southern India. Nilgiri soils are fairly homogeneous and typically exhibit organic rich horizons up to $1 \mathrm{~m}$ thick overlying deeply weathered rock. These are therefore ideally suited to a regional reconstruction. Three questions of palaeoecological interest are addressed in this paper: 
(1) do palaeobotanical signatures obtained from soil profiles on hillslopes correlate with proxy data previously obtained from peat bogs?; (2) how has the vegetation cover evolved since the LGM?; and (3) is it possible to isolate human impacts from natural variability in the palaeoenvironmental record?

\section{Materials and Methods}

\section{Geomorphic setting and soil cover}

The Nilgiris (1800-2630 m a.s.1.), or Blue Mountains, form a highland plateau located at the southern junction between the Western and Eastern Ghats escarpments of peninsular India (Figure 1). The plateau is eroded out of charnockite, a rock highly resistant to weathering (Gunnell and Louchet, 2000), flanked by precipitous, forested escarpments on all sides, and stands isolated as a topographic highland above the Karnataka plain to the north (ca. $850 \mathrm{~m}$ a.s.1.), the Tamil Nadu plain to the south and east (ca. $400 \mathrm{~m}$ a.s.1.) and the Malabar coastal lowland in Kerala (ca. $250 \mathrm{~m}$ a.s.1.). The study area covers about $1000 \mathrm{~km}^{2}$ and is defined by land located above $1800 \mathrm{~m}$ a.s. 1 . (Figure 1).

\section{Characterisation of current climatic conditions}

A dense network of meteorological stations provide good documentation on recent climatic conditions in the Nilgiris (von Lengerke, 1977). Annual rainfall is spatially variable. Three modern climatic regions were defined from the spatial distribution of the total annual rainfall. Totals range between $5000-2500 \mathrm{~mm}$ in the western region (region I on Figure 1), which receives heavy rains from the southwest monsoon, and $2000-1500 \mathrm{~mm}$ in the eastern and southern regions (III on Figure 1), where contributions from the northeast monsoon prevail in terms of seasonality but remain comparatively limited in terms of magnitude. In the central Nilgiris (region II on Figure 1), a mixed regime is observed, with totals averaging 1200-900 mm. Rainfall regimes for regions I, II and III are illustrated in Figure 3. Such spatial variability in rainfall conditions is 

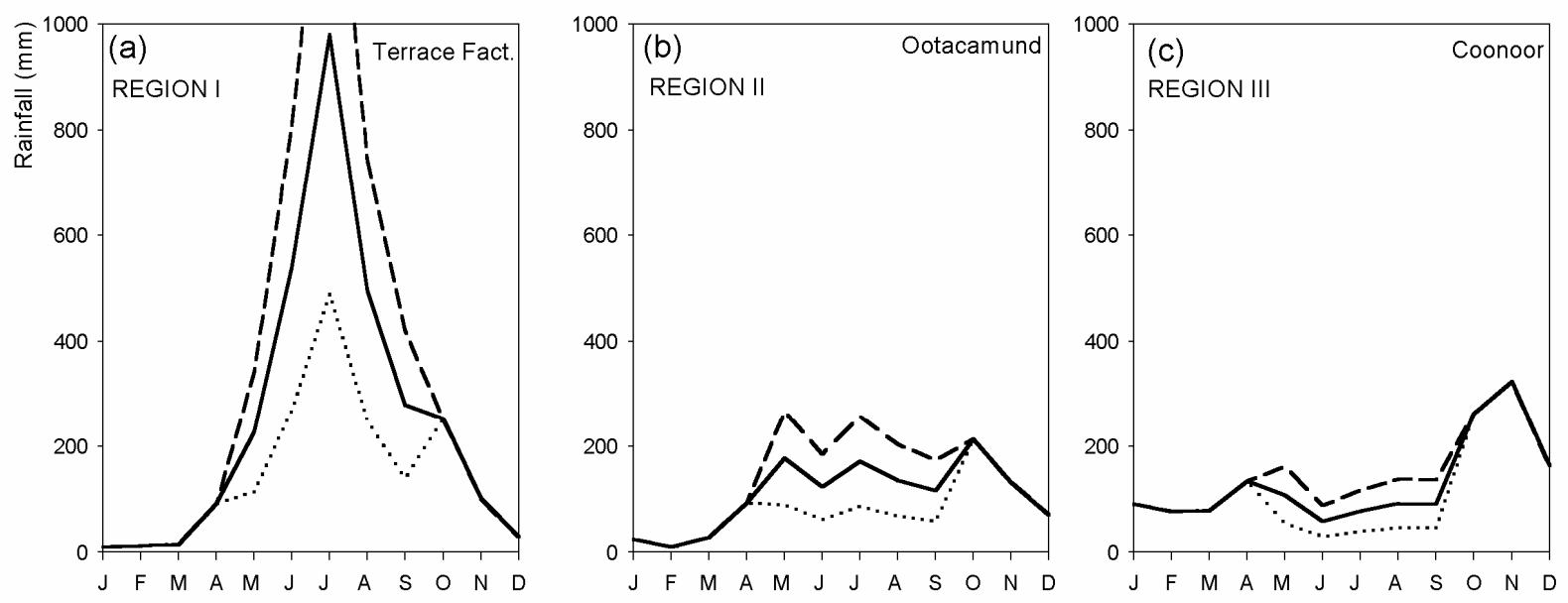

Figure 3 Rainfall regimes at raingauge stations representative of the three Nilgiri climatic regions: Terrace Factory (region I, $3038 \mathrm{~mm}$, period 1948-1972), Otacamund (region II, 1298 mm, period 1941-1972), Coonoor (region III, $1560 \mathrm{~mm}$, period 1941-1971). Black line corresponds to the current mean rainfall, the dotted line to a reduction by $50 \%$ of the southwest monsoon (hypothetical LGM conditions), and the dashed line to an increase by $50 \%$ of the southwest monsoon (hypothetical monsoon optimum conditions).

controlled by orography, and has therefore probably existed since long before the LGM. Region II, with a low density of forests confined to valley floors, receives the lowest rainfall. For comparison, evergreen forests at $1000 \mathrm{~m}$ a.s.l. on the adjacent Karnataka plateau only occur in areas where mean annual rainfall exceeds $2000 \mathrm{~mm}$ (Pascal, 1988). Annual temperatures range from a mean minimum of $5{ }^{\circ} \mathrm{C}$ in January, and a mean maximum of $24{ }^{\circ} \mathrm{C}$ in April, and nocturnal frost is common from November to March. Studies by von Lengerke (1977), who used 19401970 temperature series, indicated that nocturnal frost occurrence was mainly confined to valleys and rarely reached the upper portions of hillslopes.

\section{Characterisation of present-day vegetation patterns}

A forest map of the Nilgiris was recently prepared by Ramesh et al. (2002) and a simplified version is reproduced in Figure 1. The natural vegetation of the Nilgiris is a mosaic of evergreen forests and grasslands (Figures 1 and 2). According to the nomenclature proposed by Whitmore 
(1986) and Ashton (2003), the evergreen forests (locally named shola) fall into the category of 'tropical upper montane rain forests'. Floristically, they are dominated by members of the Lauraceae, Myrtaceae and Ericaceae families, and were mapped under the 'Litsea spp., Syzygium spp. and Microtropis spp. forest type' by Ramesh et al. (2002). Most of these species also occur in forests occupying the upper slopes of the Westen Ghats (Blasco, 1971, pp. 204-205 and Table 14 therein). Stand structure, physionomy and botanical composition varies geographically depending on slope aspect and level of disturbance. In the west, where disturbance is minimal (Naraidubetta shola of Kunda RF), the average height of canopy trees is about $15 \mathrm{~m}$, with a limited basal area. In the east (Tai shola), the canopy is higher (ca. $22 \mathrm{~m}$ ), and basal areas often reaches $70 \mathrm{~m}^{2} \cdot \mathrm{ha}^{-1}$. Further towards the eastern scarp of the massif, forests are more stunted (about $12 \mathrm{~m}$ ) and show affinities with the drier Eastern Ghats flora (presence of Oleaceae and Ebenaceae). Grasslands vary in floristic composition (Blasco, 1971), but were not differentiated on the recent forest map by Ramesh et al. (2002). In the western ranges of the Nilgiris (I on Figure 1), topography exerts a strong control over the spatial organisation of the grassland-forest land mosaic. Stunted forests are preferentially located in valleys and hollows, whereas grasslands cover large parts of the slopes and rounded crests (Figure 2). In the central region (II on Figure 1), tree plantations (acacia, eucalyptus, pine) and fields are widespread and evergreen forests patches very rare. In the eastern and southern regions (III on Figure 1), where tea gardens predominate and are interspersed with coffee estates, a few large forest patches occur that are not confined to the valleys. They thrive, instead, on steep slopes. In areas I and II, large tracts of the landscape have been deeply modified by man for at least the last 150 years. The major changes are assessed by confronting the latest vegetation map with the 1866 map of the 'Neelgherries' by C.R. Markham (Markham,1866, reproduced in Folke, 1966), the first District Gazetteer (Francis, 1908), and the first topographic map (1908-11). Before the arrival of Europeans in 1822, the Nilgiri plateau was the home of three communities known as the Todas (mostly herdsmen or graziers), the Kotas (artisans and musicians) and the Badagas (cultivators). Anthropologists report that the Toda and Kota communities established themselves around 2 ka BP, while the Badagas, only arrived in the 16th century AD (Emeneau, 1997). Francis (1908) mentions "Bellairambai, Mottakadu and Tai sholas, three of the biggest woodlands on the plateau, lying one behind the other". Nowadays, even though it is impossible to locate Mottakadu, the site lies in the same area 
as the largest Reserve Forests of the plateau. These are Tai Shola RF, Bellarambuhalla RF (new spelling of Bellairambai), and probably Kunda RF for Mottakadu (Figure 1). This overview shows that the three modern climatic regions defined earlier are relevant to the spatial distribution of 20th century vegetation map units.

\section{The soil cover}

The highland soils of the Nilgiris in different parts of the massif had remained poorly understood prior to the work of Caner et al. $(2000,2003)$ and Caner and Bourgeon (2001). They had been formerly classified into colour categories, i.e. black soils and red soils. Sehgal et al. (1996) considered the soils of the plateau as Humults (Haplohumults). This reflects the properties of the deeply weathered charnockite, its predominantly gibbsitic mineralogy, suggesting extreme weathering and great antiquity (Gunnell, 1998; Caner and Bourgeon, 2001) and the high content in organic matter. However, it has since been established (Caner et al., 2000) that the black topsoils represent organic horizons typical of cold and humid climates at high elevations in tropical regions (Van Wambeke, 1992). If sufficiently thick, such soils can fall into the category of Andisols, which are no longer required by classification standards to be tied to volcanic parent rocks.

One particular type of soil profile exhibits a dark-coloured subsurface horizon, darker than the overlying surface horizon. The Soil Taxonomy qualifies such horizons as 'sombric'. These are supposed to contain more SOM than the overlying horizon, part of the SOM corresponding to illuvial humus. This last criterion is, however, not met in Nilgiri soils (see Table 1), so these horizons have, instead, been termed sombric-like (i.e., similar to sombric horizons but lacking some of their properties). They were interpreted qualitatively by Caner et al. (2003) as indicating the replacement of grassland by forest over a time span sufficiently long to induce change in SOM type and colour. Two soil profiles sampled in the Tai Shola RF (TS1 and TS2) exhibit this sombric-like horizon. Close to Tai Shola, but under a tree plantation situated away from the forest, profile Nilg 19 also exhibits a sombric-like horizon. It testifies to the previous extent of the shola forest, and reveals the impact of deforestation, whether or not this was followed by tree plantation. 


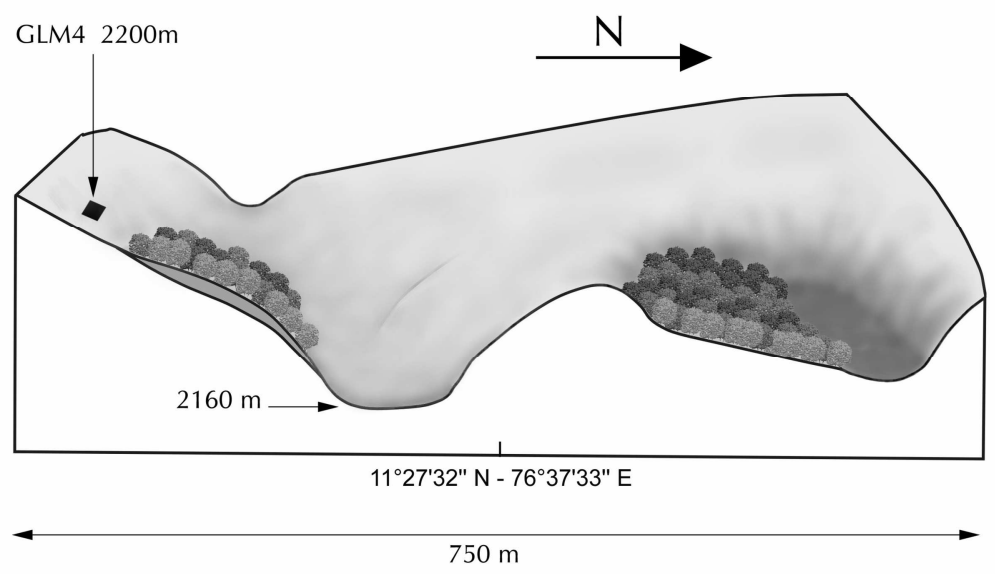

\section{Figure 4}

Respective positions of a soil profile (GLM4) and forest patches (sholas) in region II. The area shown on this block diagram constitute the upper part of a river basin. Note the present location of forest patches on the lowest part of the slope, just above the valley floor.

\section{Analytical methods of SOM analysis}

Samples were collected from 14 Andisol profiles evenly distributed throughout the three climatic regions previously defined. Given that lower hillslope concavities potentially tend to accumulate colluvium, sampling sites were systematically selected from the convex part of hillslope profiles (Figure 4). Samples were collected from each genetic horizon identified during field examination, and dried and sieved at $2 \mathrm{~mm}$. Prior to the $\delta^{13} \mathrm{C}$ measurements and ${ }^{14} \mathrm{C}$ dating, that were made on the same subsample, soil was sieved at $50 \mu \mathrm{m}$ in order to remove most of the debris (roots, wood fragments) from the current vegetation and so avoid contamination by recent material (Balesdent et al., 1987; Bowman and Cook, 2002).

For profiles Nilg4, Nilg16, Nilg19 and Kota0, $\delta^{13} \mathrm{C}$ was determined at the Centre de Recherches Pétrographiques et Géologiques (CRPG-CNRS, Nancy, France) using a VG 602D Micromass mass spectrometer (analytical precision: $\pm 0.1 \%$ ). The standards used were graphite (standard USGS $24, \delta^{13} \mathrm{C}=-16.1 \%$ ) and oil (standard NBS $22, \delta^{13} \mathrm{C}=-29.7 \%$ ). For other profiles, $\delta^{13} \mathrm{C}$ was measured using an elemental analyser (Carlo Erba, NA1500-NC) coupled to a Finnigan delta$\mathrm{S}$ mass spectrometer (analytical precision: $\pm 0.2 \%$ ) at the Institut National de la Recherche 
Agronomique, Nancy (France). The standard used was polyethylene (standard IAEA-CH-7, $\delta^{13} \mathrm{C}$ $=-31.8 \%$ ). Results are expressed as $\delta^{13} \mathrm{C}$ relative to the VPDB standard according to the formula:

$\delta^{13} \mathrm{C}=\left[\left({ }^{13} \mathrm{C} /{ }^{12} \mathrm{C}\right)_{\text {sample }} /\left({ }^{13} \mathrm{C} /{ }^{12} \mathrm{C}\right)_{\text {standard }}-1\right] \times 1000$

Radiocarbon dating of SOM is based on the decay of ${ }^{14} \mathrm{C}$ in plant debris, which has a ${ }^{14} \mathrm{C} /{ }^{12} \mathrm{C}$ ratio similar to that of atmospheric $\mathrm{CO}_{2}$ during the plant's life. Radiocarbon ages were obtained by the liquid scintillation method (Balesdent and Guillet, 1982) at the Centre de Datation au Radiocarbone (CDRC, University of Lyon, France). Radiocarbon ages are expressed in ${ }^{14} \mathrm{C}$ years BP normalized to a $\delta^{13} \mathrm{C}$ of $-25 \%$. For surface samples $(0-20 \mathrm{~cm})$, a mean residence time (MRT) was calculated using a model that takes into account bomb ${ }^{14} \mathrm{C}$ deriving from nuclear tests until the sampling date (1996) (Balesdent and Guillet, 1982). For deeper samples (20-120 cm), ages were obtained using a half-life of 5568 years with the following formula:

Age $=-8035 \ln \left[1+\left(\Delta^{14} \mathrm{C} / 1000\right)\right]$

The use of MRT as a means of dating soil organic matter has been discussed by Balesdent and Guillet (1982). Its relevance to this study is tied to the fact, explained earlier, that the organometallic complexes in the Nilgiri soils stabilize the SOM, particularly guarding it against mineralization and $\mathrm{CO}_{2}$ production. This does not imply that $\mathrm{SOM}$ is immobilized and immune from down-profile leaching, but MRT in soils can be used as a substitute for conventional ${ }^{14} \mathrm{C}$ age in sediments because downward SOM redistribution within profiles is excessively slow. As shown in the Results section, this seems confirmed by the good match between MRT data and peat ages obtained independently from the same area.

\section{Results}

Results concerning the SOM analysis of 14 soil profiles are presented in Table 1. A detailed description of the soils was given in Caner et al. $(2000,2003)$. Soils present high contents in 
organic carbon up to a depth of $1 \mathrm{~m}$. These high contents are due to the presence of organometallic complexes. To estimate their amounts, which cannot be directly measured, we multiplied the amount of $\mathrm{Al}$ extracted by sodium pyrophosphate (noted $\mathrm{Al}_{\mathrm{p}}$ ) by a factor varying between 7.5 and 12 as proposed by Poulenard and Herbillon (2000). Here we chose the mean, i.e. 9.75. For $\mathrm{Al}_{\mathrm{p}}$ contents ranging between 4 and $23 \mathrm{~g} \cdot \mathrm{kg}^{-1}$ of the fine earth $(<2 \mathrm{~mm})$ fraction (Table 1), estimates of the amounts of stable organo-metallic complexes (Al- and Fe-humus complexes) range between 39 and $224 \mathrm{~g} \cdot \mathrm{kg}^{-1}$ (not shown in Table 1). The highest values are found in the subsurface horizons of some of the soils of the western and central regions. As these organo-metallic complexes are highly resistant to biodegradation (Boudot et al., 1986, Sollins et al. 1996), SOM is stabilized for long periods of time and will retain information on past land cover change.

Delta ${ }^{13} \mathrm{C}$ was plotted against depth in Figure 5 for all the profiles, and against mean age (i.e., MRT) in Figure 6 for five profiles. The most striking feature in all the profiles is the decrease in contribution from $\mathrm{C}_{4}$ plants towards the soil surface (Table 1, Figure 5). The combination of $\delta^{13} \mathrm{C}$ and ${ }^{14} \mathrm{C}$ data down profile allows to postulate that significant vegetation changes have occurred on the Nilgiri plateau and that they were not spatially uniform.

SOM in surface horizons derives either from $C_{3}$ plants (Nilg 4, UB 3, Nilg 19, TS 1, TS 2 and Kota 0 ) or from a mixture of $\mathrm{C}_{3}$ and $\mathrm{C}_{4}$ plants (other profiles). This is in agreement with the dominant floristic compositions currently observed at all the selected sites (Table 1, column 1). Profiles exhibiting a sombric-like horizon (indicated by * in Table 1) must be distinguished from the others because this feature indicates that forest expansion on former grasslands is rather old (probably several centuries if we consider the MRT of SOM in the $15-25 \mathrm{~cm}$ horizon of profile Nilg 19), and occurred long before reforestation undertaken by the Forest Department. In some cases, tree plantations are nowadays replacing these old forests (e.g. Nilg 19, Kota 0, Kota 1 and Kota 4).

At depth, SOM derives from $\mathrm{C}_{4}$-plants for seven profiles, and is of a mixed origin for the remaining seven. Where ${ }^{14} \mathrm{C}$ ages were obtained (Table 1 and Figure 6), we observe an SOM MRT compatible with a LGM age in two cases: Nilg 16 and Kota 0 . These represent the longest reported ${ }^{14} \mathrm{C}$ record for soil in southern India and results are consistent with the data obtained from peat bogs (Sukumar et al., 1993).

TABLE 1 Location, soil characteristics and carbon isotope data of the selected soils 


\begin{tabular}{|c|c|c|c|c|c|c|}
\hline $\begin{array}{l}\text { Profile } \\
\text { Vegetation }\end{array}$ & $\begin{array}{c}\text { Location } \\
\mathrm{x}, \mathrm{y}, \mathrm{z}\end{array}$ & $\begin{array}{c}\text { Depth } \\
(\mathrm{cm})\end{array}$ & $\begin{array}{r}\mathrm{Al}_{\mathrm{p}} \\
\left(\mathrm{g} \cdot \mathrm{kg}^{-1}\right) \\
\end{array}$ & $\begin{array}{c}\mathrm{C}<50 \mu \mathrm{m} \\
\left(\mathrm{g} \cdot \mathrm{kg}^{-1}\right)\end{array}$ & $\begin{array}{l}\delta^{13} \mathrm{C} \\
(\% 0)\end{array}$ & $\begin{array}{c}\text { MRT\# } \\
\text { (years BP) } \\
\end{array}$ \\
\hline \multicolumn{7}{|c|}{ Soils of the Western region (I) } \\
\hline $\begin{array}{l}\text { Nilg } 4 \\
\text { Shola }\end{array}$ & $\begin{array}{c}11^{\circ} 17^{\prime} 56^{\prime \prime} \mathrm{N} \\
76^{\circ} 35^{\prime} 57^{\prime \prime} \mathrm{E} \\
2200 \mathrm{~m}\end{array}$ & $\begin{array}{c}0-10 \\
15-30 \\
40-60 \\
65-75\end{array}$ & $\begin{array}{r}18.2 \\
18.2 \\
6.8 \\
\text { nd }\end{array}$ & $\begin{array}{r}112 \\
65 \\
46 \\
22\end{array}$ & $\begin{array}{l}-24.2 \\
-19.8 \\
-14.4 \\
-12.5\end{array}$ & $\begin{array}{c}153 \pm 20 \\
1140 \pm 42 \\
4100 \pm 52 \\
\text { nd }\end{array}$ \\
\hline $\begin{array}{l}\text { Nilg } 16 \\
\text { Acacia } \\
\text { plantation }\end{array}$ & $\begin{array}{c}11^{\circ} 24^{\prime} 57^{\prime \prime} \mathrm{N} \\
76^{\circ} 34^{\prime} 50^{\prime \prime} \mathrm{E} \\
2100 \mathrm{~m}\end{array}$ & $\begin{array}{c}0-10 \\
20-35 \\
40-50 \\
60-75 \\
75-90\end{array}$ & $\begin{array}{l}17.4 \\
23.1 \\
21.8 \\
16.6 \\
16.3\end{array}$ & $\begin{array}{r}127 \\
90 \\
68 \\
38 \\
35\end{array}$ & $\begin{array}{l}-17.5 \\
-12.5 \\
-11.1 \\
-12.4 \\
-11.8\end{array}$ & $\begin{array}{c}108 \pm 9 \\
826 \pm 39 \\
2814 \pm 42 \\
19715 \pm 160 \\
26213 \pm 299\end{array}$ \\
\hline $\begin{array}{l}\text { Nilg } 18 \\
\text { Acacia } \\
\text { plantation }\end{array}$ & $\begin{array}{c}11^{\circ} 22^{\prime} 28^{\prime \prime} \mathrm{N} \\
76^{\circ} 35^{\prime} 19^{\prime \prime} \mathrm{E} \\
2200 \mathrm{~m}\end{array}$ & $\begin{array}{c}0-15 \\
15-35 \\
35-60 \\
60-80 \\
80-85\end{array}$ & $\begin{array}{r}17.5 \\
20.0 \\
20.0 \\
8.8 \\
4.3\end{array}$ & $\begin{array}{r}117 \\
114 \\
53 \\
22 \\
10\end{array}$ & $\begin{array}{l}-16.8 \\
-15.7 \\
-14.4 \\
-11.0 \\
-10.9\end{array}$ & \\
\hline $\begin{array}{l}\mathrm{UB} 1 \\
\text { Acacia } \\
\text { plantation }\end{array}$ & $\begin{array}{c}11^{\circ} 13^{\prime} 30^{\prime \prime} \mathrm{N} \\
76^{\circ} 32^{\prime} 31^{\prime \prime} \mathrm{E} \\
2360 \mathrm{~m}\end{array}$ & $\begin{array}{c}0-10 \\
30-50 \\
50-60 \\
70-90 \\
100-120\end{array}$ & $\begin{array}{r}9.3 \\
14.9 \\
9.1 \\
3.9 \\
\text { nd }\end{array}$ & $\begin{array}{l}84 \\
55 \\
26 \\
11 \\
10\end{array}$ & $\begin{array}{l}-21.6 \\
-17.6 \\
-16.2 \\
-16.3 \\
-16.3\end{array}$ & \\
\hline $\begin{array}{l}\text { UB } 3 \\
\text { Acacia } \\
\text { plantation }\end{array}$ & $\begin{array}{c}11^{\circ} 16^{\prime} 30^{\prime \prime} \mathrm{N} \\
76^{\circ} 34^{\prime} 42^{\prime \prime} \mathrm{E} \\
2350 \mathrm{~m}\end{array}$ & $\begin{array}{c}0-10 \\
20-30 \\
40-50 \\
60-70\end{array}$ & $\begin{array}{r}12.6 \\
16.6 \\
7.4 \\
\text { nd }\end{array}$ & $\begin{array}{r}156 \\
83 \\
21 \\
10\end{array}$ & $\begin{array}{l}-23.1 \\
-16.1 \\
-11.5 \\
-15.4\end{array}$ & \\
\hline $\begin{array}{l}\text { MP } 2 \\
\text { Acacia } \\
\text { plantation }\end{array}$ & $\begin{array}{c}11^{\circ} 23^{\prime} 32^{\prime \prime} \mathrm{N} \\
76^{\circ} 34^{\prime} 11^{\prime \prime} \mathrm{E} \\
2150 \mathrm{~m}\end{array}$ & $\begin{array}{c}0-10 \\
20-50 \\
50-65 \\
100-120\end{array}$ & $\begin{array}{r}12.9 \\
17.1 \\
10.7 \\
\text { nd }\end{array}$ & $\begin{array}{r}133 \\
47 \\
21 \\
4\end{array}$ & $\begin{array}{l}-21.2 \\
-16.3 \\
-14.5 \\
-16.9\end{array}$ & \\
\hline \multicolumn{7}{|c|}{ Soils of the central region (II) } \\
\hline $\begin{array}{l}\text { Nilg } 20 \\
\text { Acacia } \\
\text { plantation }\end{array}$ & $\begin{array}{c}11^{\circ} 24^{\prime} 04^{\prime \prime} \mathrm{N} \\
76^{\circ} 39^{\prime} 17^{\prime \prime} \mathrm{E} \\
2250 \mathrm{~m}\end{array}$ & $\begin{array}{c}0-10 \\
25-45 \\
45-60 \\
80-100\end{array}$ & $\begin{array}{l}\text { nd } \\
\text { nd } \\
\text { nd } \\
\text { nd }\end{array}$ & $\begin{array}{r}70 \\
30 \\
20 \\
9\end{array}$ & $\begin{array}{r}-20.1 \\
-12.3 \\
-9.8 \\
-9.9\end{array}$ & $83 \pm 6$ \\
\hline $\begin{array}{l}\text { GLM } 4 \\
\text { Grassland } \\
\text { with gorse }\end{array}$ & $\begin{array}{c}11^{\circ} 27^{\prime} 21^{\prime \prime} \mathrm{N} \\
76^{\circ} 37^{\prime} 21^{\prime \prime} \mathrm{E} \\
2200 \mathrm{~m}\end{array}$ & $\begin{array}{c}0-10 \\
30-40 \\
40-55 \\
70-80\end{array}$ & $\begin{array}{l}18.2 \\
21.5 \\
20.4 \\
21.9\end{array}$ & $\begin{array}{l}79 \\
60 \\
25 \\
14\end{array}$ & $\begin{array}{r}-16.7 \\
-14.5 \\
-13.5 \\
-9.9\end{array}$ & $\begin{array}{c}267 \pm 26 \\
1222 \pm 60\end{array}$ \\
\hline
\end{tabular}

Profile Location Depth $\quad \mathrm{Al}_{\mathrm{p}} \quad \mathrm{C}<50 \mu \mathrm{m} \quad \delta^{13} \mathrm{C} \quad$ MRT\#




\begin{tabular}{|c|c|c|c|c|c|c|}
\hline Vegetation & $\mathrm{x}, \mathrm{y}, \mathrm{z}$ & $(\mathrm{cm})$ & $\left(\mathrm{g} \cdot \mathrm{kg}^{-1}\right)$ & $\left(\mathrm{g} \cdot \mathrm{kg}^{-1}\right)$ & $(\%)$ & (years BP) \\
\hline \multicolumn{7}{|c|}{ Soils of the Southern and Eastern regions (III) } \\
\hline $\begin{array}{l}\text { Nilg } 19 * \\
\text { Acacia } \\
\text { plantation }\end{array}$ & $\begin{array}{c}11^{\circ} 13^{\prime} 02^{\prime \prime} \mathrm{N} \\
76^{\circ} 37^{\prime} 19^{\prime \prime} \mathrm{E} \\
2100 \mathrm{~m}\end{array}$ & $\begin{array}{c}0-10 \\
15-25 \\
25-40 \\
60-70 \\
70-80 \\
100-120\end{array}$ & $\begin{array}{r}14.6 \\
16.9 \\
16.9 \\
13.7 \\
5.4\end{array}$ & $\begin{array}{r}140 \\
160 \\
160 \\
130 \\
130 \\
50\end{array}$ & $\begin{array}{l}-23.1 \\
-22.3 \\
-22.4 \\
-15.2 \\
-15.9 \\
-14.9\end{array}$ & $\begin{array}{c}85 \pm 20 \\
277 \pm 34 \\
2192 \pm 50 \\
13245 \pm 81\end{array}$ \\
\hline $\begin{array}{l}\text { TS } 1 * \\
\text { Shola }\end{array}$ & $\begin{array}{c}11^{\circ} 12^{\prime} 44^{\prime \prime} \mathrm{N} \\
76^{\circ} 37^{\prime} 18^{\prime \prime} \mathrm{E} \\
1812 \mathrm{~m}\end{array}$ & $\begin{array}{c}0-10 \\
25-35 \\
40-50 \\
65-75 \\
110-120\end{array}$ & $\begin{array}{l}18.7 \\
23.2 \\
17.2 \\
10.1\end{array}$ & $\begin{array}{r}182 \\
79 \\
49 \\
40 \\
10\end{array}$ & $\begin{array}{l}-26.6 \\
-20.7 \\
-19.9 \\
-17.6 \\
-20.4\end{array}$ & \\
\hline $\begin{array}{l}\text { TS 2* } \\
\text { Shola }\end{array}$ & $\begin{array}{c}11^{\circ} 12^{\prime} 39^{\prime \prime} \mathrm{N} \\
76^{\circ} 36^{\prime} 14^{\prime \prime} \mathrm{E} \\
1908 \mathrm{~m}\end{array}$ & $\begin{array}{c}0-10 \\
20-40 \\
40-90 \\
110-120\end{array}$ & $\begin{array}{r}5.8 \\
12.8 \\
18.6\end{array}$ & $\begin{array}{r}225 \\
58 \\
45 \\
34\end{array}$ & $\begin{array}{l}-27.5 \\
-24.3 \\
-16.6 \\
-13.3\end{array}$ & \\
\hline $\begin{array}{l}\text { Kota } 0^{*} \\
\text { Acacia } \\
\text { plantation }\end{array}$ & $\begin{array}{c}11^{\circ} 24^{\prime} 55^{\prime \prime} \mathrm{N} \\
76^{\circ} 49^{\prime} 24^{\prime \prime} \mathrm{E} \\
2100 \mathrm{~m}\end{array}$ & $\begin{array}{c}0-20 \\
30-40 \\
50-65 \\
80-90 \\
100-120\end{array}$ & $\begin{array}{l}10.3 \\
11.5 \\
16.2 \\
9.8\end{array}$ & $\begin{array}{l}100 \\
100 \\
110 \\
160\end{array}$ & $\begin{array}{l}-23.2 \\
-15.8 \\
-14.8 \\
-12.9 \\
-12.9\end{array}$ & $\begin{array}{c}62 \pm 4 \\
4054 \pm 51 \\
4811 \pm 59 \\
20411 \pm 154 \\
21171 \pm 206\end{array}$ \\
\hline $\begin{array}{l}\text { Kota } 1^{*} \\
\text { Acacia } \\
\text { plantation }\end{array}$ & $\begin{array}{c}11^{\circ} 26^{\prime} 58^{\prime \prime} \mathrm{N} \\
76^{\circ} 54^{\prime} 40^{\prime \prime} \mathrm{E} \\
1850 \mathrm{~m}\end{array}$ & $\begin{array}{l}0-30 \\
30-50 \\
60-70 \\
70-90\end{array}$ & $\begin{array}{r}17.8 \\
17.5 \\
5.8\end{array}$ & $\begin{array}{r}174 \\
170 \\
55\end{array}$ & $\begin{array}{l}-18.1 \\
-18.5 \\
-15.1 \\
-14.4\end{array}$ & \\
\hline $\begin{array}{l}\text { Kota } 4 * \\
\text { Acacia } \\
\text { plantation }\end{array}$ & $\begin{array}{c}11^{\circ} 25^{\prime} 25^{\prime \prime} \mathrm{N} \\
76^{\circ} 49^{\prime} 55^{\prime \prime} \mathrm{E} \\
2000 \mathrm{~m}\end{array}$ & $\begin{array}{c}0-10 \\
20-40 \\
40-90 \\
90-100\end{array}$ & $\begin{array}{r}11.8 \\
16.2 \\
8.7\end{array}$ & $\begin{array}{r}115 \\
158 \\
85\end{array}$ & $\begin{array}{l}-20.1 \\
-19.1 \\
-18.3 \\
-15.5\end{array}$ & \\
\hline
\end{tabular}

\# MRT : Mean residence time, is an uncorrected ${ }^{14} \mathrm{C}$ age (see text)

* Soil profiles exhibiting a sombric-like horizon

In the two profiles, a sharp downward increase in ages is also observed. Clearly, lines on Fig. 6 connect discrete data points that may have missed important spikes of forest expansion between ca. 19 and ca. 4 ka BP. However the older ages are correlated with remarkably sharp $\mathrm{C}_{4}$ signatures and high contents in organo-metallic complexes responsible for the stabilisation of SOM over long periods (Guillet et al., 1988). If a forest expansion spike, undetected by our sampling, had occurred between 19 and $4 \mathrm{ka} \mathrm{BP}$, it is likely that its $\mathrm{C}_{3}$ SOM would have also contaminated the deeper organic horizons. The deep horizons would therefore not exhibit such sharp $\mathrm{C}_{4}$ signatures. 

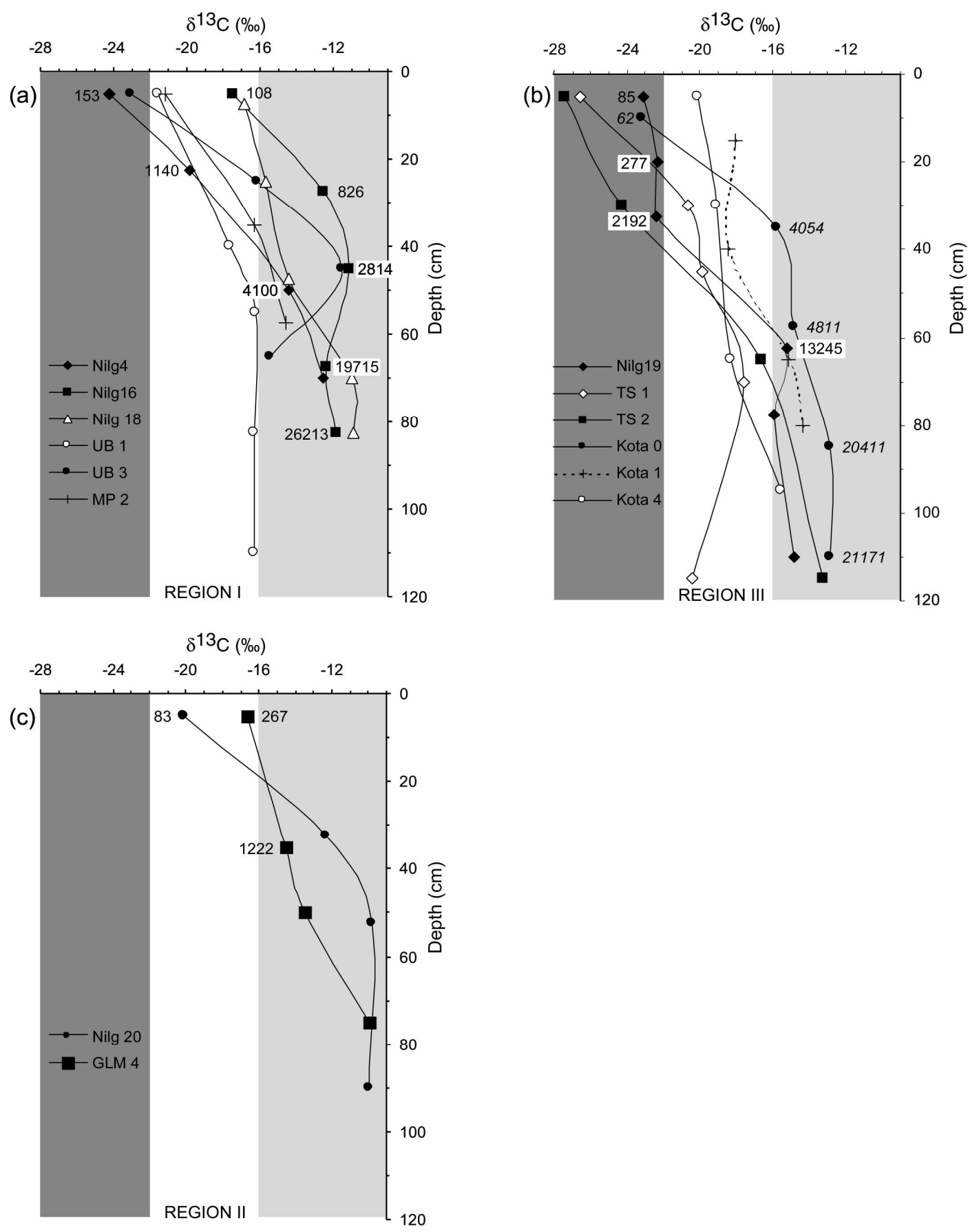

Figure 5 Profiles of $\delta^{13} \mathrm{C}$ for the soils of the three main climatic regions of the Nilgiris. (a) Western region I, (b) central region II, and (c) eastern and southern regions III. Following domain definitions given in Boutton et al. (1998), light grey and dark grey shading correspond to areas of predominant $\mathrm{C}_{4}$-plant-derived SOM ( -9 to $-12 \%$ ) and $\mathrm{C}_{3}$-plant-derived SOM (-22 to $-28 \%$ ), respectively. Sample radiocarbon age (in years BP, sœ Table 1 for uncertainty envelopes) is indicated when available. 


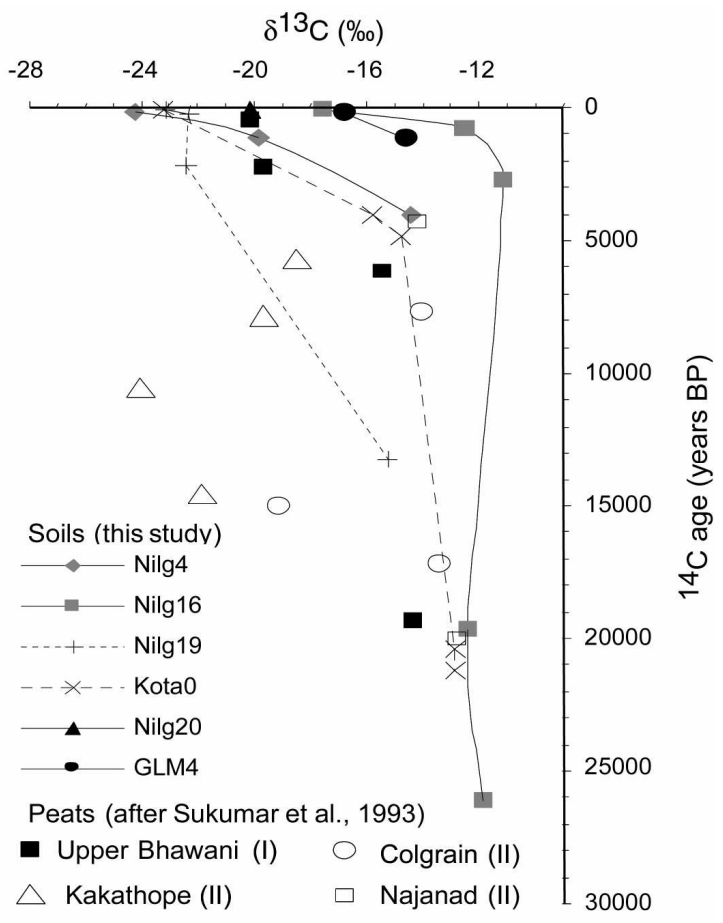

Figure 6 Relationship between $\delta^{13} \mathrm{C}$ and ${ }^{14} \mathrm{C}$ age for soil samples from six soil profiles. These data reveal the antiquity of SOM in Kota 0 (21.2 ka BP) and Nilg 16 (26.2 ka BP), implying long-term stability of these soils under grassland. Values obtained by Sukumar et al. (1993) on peat bog samples (the corresponding regions are indicated in parenthesis) have also been plotted on this graph. They highlight discrepancies with soil results, particularly between 15 and $10 \mathrm{ka} \mathrm{BP}$.

\section{Discussion}

\section{Palaeoclimatic inferences based on the soil record of vegetation change}

Given the tangible effects of frost hazard in these tropical highlands under current interglacial conditions (cf. supra), low temperatures constitute, and have probably constituted, the main limiting factor of forest expansion since $20 \mathrm{ka} \mathrm{BP}$ in the Nilgiris. In their synthesis, Farrera et al. (1999) reported that LGM mean temperatures were $5{ }^{\circ} \mathrm{C}$ below present figures for the Nilgiris. Accordingly, we apply here a simple sensitivity test in which we estimate palaeoclimatic conditions during the LGM based on a temperature fall of $5{ }^{\circ} \mathrm{C}$. Given the consensual view that monsoon rainfall was lower during glacial that during interglacial epochs (e.g. Rostek et al., 1993; Bassinot 
et al., 1994; Prabhu et al., 2004), we further postulate that southwest monsoon rainfall totals fell by $50 \%$ compared to the present during months from June to September. Under this hypothesis, represented on Figure 3, annual rainfall totals would have dropped to 1776, 1346 and $935 \mathrm{~mm}$ for Terrace Factory (I), Coonoor (III) and Ootacamund (II), respectively. At Terrace Factory, such diminished rainfall totals nevertheless remain similar to present-day rainfall totals in the eastern and southern regions, where evergreen stands currently exist. However, under the colder conditions that seem directly applicable to the Nilgiri setting, the tree line probably never extended above $1800 \mathrm{~m}$ a.s.1. This means that despite sufficient rainfall in region $\mathrm{I}$, forests retreated to warmer refuges situated below the plateau surface, i.e. to the outer escarpments that connect with the surrounding plains. Unlike Sukumar et al. (1993), who attributed late Pleistocene variability in vegetation patterns mostly to variability in monsoon rainfall, we therefore conclude that prevalence of grassland vegetation during the LGM was primarily caused by colder rather than by drier conditions. This would have been particularly true for the valley settings and the peat record, where local temperature inversions would have been even more pronounced than today (von Lengerke, 1977). Locally, insufficient rainfall, strong winds (atmospheric drought) and fires, which are reported from other tropical areas (Guillet et al., 1988; Pessenda et al., 2001; Bowman et al., 2004), could have played as additional factors.

Rainfall conditions at the monsoon optimum (i.e., $11 \mathrm{ka}$ BP) can be similarly simulated by postulating a $50 \%$ increase on current conditions of southwest monsoon rainfall totals between June and September (see Figure 3). Under this hypothesis, annual rainfall would have reached 4300, 1774 and $1661 \mathrm{~mm}$ for Terrace Factory, Coonoor and Ootacamund, respectively. The simulated rainfall total thus obtained for Ootacamund is probably sufficient to explain the expansion of forests into region II during this period, in agreement with interpretations made by Sukumar et al. (1995) and Rajagopalan et al. (1997). We are not aware of data that could imply, in addition to rainfall totals, that changes in monsoon seasonality were also an influential factor. Likewise, post-LGM variability in the northeast monsoon (winter monsoon) remains poorly documented in the literature because most of the research effort has, historically, focused on the southwest monsoon (summer monsoon). Evidence recently investigated indicates nevertheless that, on average, summer monsoon deficits (e.g. during colder epochs in Eurasia) tend to coincide with winter monsoon deficits (Gunnell et al., in press); i.e., it is probably simplistic to consider the 
monsoon system as just a giant sea breeze (see also Gadgil, 2003), in which rainfall totals are a simple function of thermally driven winds blowing seasonally in opposite directions. This could explain why, for instance, we do not detect forest vegetation in region (III) during the LGM despite the intuitive but flawed logic according to which a weaker summer monsoon should systematically promote higher rainfall during the winter monsoon.

\section{Correlation between hillslope soil and valley peat data}

The general trend illustrated by the $\delta^{13} \mathrm{C}$ profiles (Figure 5) is the replacement of grassland vegetation by $\mathrm{C}_{3}$ vegetation in almost all the studied sites, and this trend corroborates one of the main conclusions of Sukumar et al. (1993). However, as documented by the ${ }^{14} \mathrm{C}$ dating, the time at which this replacement occurred differs from one site to another, and this is partly at odds with the time-indexed baseline of vegetation evolution proposed for the entire Nilgiri massif from the peat bog record. The soil data distinguish two contrasting situations: (1) sites where substitution of forest by grassland has occurred recently as a consequence of deforestation; and (2) sites where forest replacement was natural because it occurred earlier than the first known human settlement. The first case (e.g., Nilg 16, Nilg 18 , etc.) is typified by a high $\mathrm{Al}_{\mathrm{p}}$ content in subsurface horizons and a pure $\mathrm{C}_{4}$ signature at depth. In the second case (e.g., Nilg 19, Kota 4, etc., which exhibit an sombric-like horizon), the $\mathrm{Al}_{\mathrm{p}}$ content in subsurface horizons is comparatively low and the $\delta^{13} \mathrm{C}$ signatures at depth correspond to a mixed origin $\left(\mathrm{C}_{3}\right.$ and $\mathrm{C}_{4}$ plants $)$.

Despite the fact that MRT provides a mean apparent age which is younger than the true age of the oldest component of soil carbon in the heterogeneous SOM pool (whereas peat stratigraphy is, in theory, exempt from mixing), the values obtained by Sukumar et al. (1993) for peat samples were plotted on Figure 6. The peat data outline a distinction between a bog (Upper Bhawani basin) located in the western region I, and the four other bogs (Colgrain, Sandynallah, Kakathope, Nanjanad) located in the central region II. In Figure 6, points representing peat samples from region I (Upper Bhawani) plot very close to the curves representing soil profiles from that same area (Nilg 4 Nilg 16, Nilg 18). In contrast, the peat samples analysed in region II (Najanad, Colgrain) record a decrease in $\delta^{13} \mathrm{C}$ between 13 and $10 \mathrm{ka}$ BP (i.e., the monsoon optimum) with no detected equivalent in the soil samples analysed. This constitutes a second important 
discrepancy between results obtained from peat and soil samples. Based on a region by region comparison of the shapes of $\delta^{13} \mathrm{C}$ curves between the undated profiles of Figure 5 and the timeindexed ones of Figure 6, it seems highly unlikely that the soil profiles for which ${ }^{14} \mathrm{C}$ dates are not available recorded a chronology of land cover change different from the dated profiles.

In peat samples from the Colgrain bog, the shift of isotopic signatures towards low values of $\delta^{13} \mathrm{C}$ was accompanied by an increase of forest species in the pollen spectra (Gupta and Prasad, 1985). This clearly indicates forest expansion, at least in the vicinity of the bog. The fact that the two soil profiles (GLM 4 and Nilg 20) located in the same central region II as the four peat bogs (Figure 1) did not record the same vegetation succession pattern suggests that topography could have been the main differentiating factor. The soil profiles being located 20 to $40 \mathrm{~m}$ higher in the landscape than the bogs, forest expansion, while tangible around valley floors on alluvium and colluvium, would not have reached topographically steeper and more elevated sites on the Al-rich soils of the slopes (Figure 4).

\section{A qualitative model of Holocene landscape sensitivity to rainfall and temperature}

This study on vegetation evolution in the Nilgiri highlands reveals that historical intricacies and spatial heterogeneities could not have been deduced just from peat bog analysis. This is mainly due to the fact that the few bogs are unevenly distributed across the plateau. Instead of the uniform, Nilgiri-wide scenario outlined by Sukumar et al (1993); and despite the consensual situation during the drier and colder LGM in which the grasslands invaded the entire plateau, here we propose three distinct post-LGM palaeoecological trajectories in which climatic factors have had varying impacts depending on the sub-region considered.

(1) In the west (region I), beaten by strong winds, the forests have expanded in the relatively sheltered valleys and have never invaded the slopes still occupied by grassland. According to our data and those collected from the only peat bog in that area, this process is recorded as a slow and steady expansion of forest. Therefore, the forest-grassland mosaic need not be interpreted as the result of fragmentation of a forest continuum by humans. In this region, human disturbances are comparatively recent and consist mostly of tree plantations on former grassland by the Forest Department. 
(2) In region III (east and south), which is less sensitive to southwest monsoon fluctuations, progressive warming after the LGM allowed the early expansion of a forest cover, even on the upper part of some slopes. The SOM produced by forest stands has altered the characteristics of the SOM inherited from the LGM grasslands. This has generated a particular kind of soil profile exhibiting "sombric-like" horizons. That forest cover was partly cleared by Badaga cultivators after the 16th century AD, and was further fragmented by European settlers during the 19th and 20 th centuries.

(3) Unlike the two other regions, the vegetation cover of the central region (II) has been highly sensitive to southwest monsoon fluctuations during the last $20 \mathrm{ka}$ because rainfall totals are critically low. A phase of forest expansion during the monsoon optimum at ca. $11 \mathrm{ka}$ BP was followed by a regression of forest cover leading to the currently observed mosaic state, i.e., few forest patches surrounding bogs and grasslands. As a result, this open and relatively sheltered landscape was, alongside the southern and eastern Nilgiris where forest had already been cleared by the Badagas, the easiest area for settlers to develop a plantatation economy, as confirmed by Markham's 1866 map (Markham, 1866) of the first Nilgiri cinchona plantations directly around the largest city, Ootacamund.

The behaviour of region II compared to region I highlights the importance of thresholds in qualitative system-state changes. This behaviour is typical of ecotones, whereby climatic changes in the soil or fossil record will register more sharply near a vegetation boundary than in ecological core zones where greater amplitudes of climatic change are necessary to make an imprint on the fossil record. Purely quantitative variations need not steer landscape away from a steady, or even possibly stable, state if variability in rainfall does not cross a certain critical threshold: this is observed in the western Nilgiris, where halving mean annual rainfall in this core humid area would have caused little change to the landscape mosaic. Wind strength has remained the main inhibitor of forest colonisation on hilltops, and a range of recent studies suggests that colder epochs of the Pleistocene in South Asia involved drier climates (Rostek et al., 1993; Bassinot et al., 1994; Prabhu et al., 2004) but not necessarily diminished southwest monsoon wind strengths (Beaufort, 1996; Cayre et al., 1999). The data here support this conclusion. In contrast, ecocline conditions in region II make the environment more sensitive to small variations in rainfall and temperature. Such sensitivity of ecocline conditions to Quaternary paleoclimatic fluctuations had previously 
been analysed further north, on the Karnataka plateau, in the rainshadow of the Western Ghats great escarpment by Gunnell and Bourgeon (1997) and Gunnell (2000).

\section{Conclusion}

The Nilgiri highlands have long been studied for continental paleoenvironments in southern India. This study, which is the first long-term record of vegetation dynamics based on SOM carbon isotope in this area, supplements and refines previous results provided by the study of peat bogs. It reveals a spatially and chronologically more heterogeneous picture of past land cover change than previously considered, in which a subtle interplay between palaeotemperature, palaeorainfall, topography and regional climatic gradients is highlighted. Because the soil record allows a sampling strategy that advantageously complements information acquired form valley peat bogs, even within a small region ca. $1000 \mathrm{~km}^{2}$ such as the Nilgiris, the overall picture of landscape evolution is revealed to be considerably less simplistic than either local-scale (e.g., peat bog) or global-scale (chiefly oceanic) environmental archives can convey.

Finally, from an ecosystems conservation viewpoint, the gain in time depth and spatial understanding of the shifting land mosaic afforded by this study suggests the following recommendations: (1) forests and grasslands are equally natural and must be protected together (this is more or less done today, although purely in terms of habitat diversity and without any grasp of the historical perspective presented in this paper); (2) tree plantation in grasslands and forest fragmentation must each be considered equally as threats to the natural mosaic ecosystem; (3) for wildlife ecology, understanding how forest animal species have co-evolved with the shifting mosaic is probably as relevant an issue as establishing how the number of existing species are coping with forest fragmentation under human pressure over the last two centuries.

\section{References}

Ashton, P. S. 2003: Floristic zonation of tree communities on wet tropical mountains revisited. Perspectives in Plant Ecology, Evolution and Systematics. A tribute volume for the late Dr T. C. Whitmore 6, 87-104.

Aubréville, A. M. A. 1947: La mort des forêts de l'Afrique tropicale. Unasylva, 1 [reproduced in Unasylva, 1985, 37, 18-27]. 
Balesdent, J. and Guillet, B. 1982: Les datations par le ${ }^{14} \mathrm{C}$ des matières organiques des sols. Contribution à l'étude de l'humification et du renouvellement des substances humiques. Science du Sol 2, 93-111.

Balesdent, J. Mariotti, A. and Guillet, B. 1987: Natural ${ }^{13} \mathrm{C}$ abundance as a tracer for soil organic matter dynamics studies. Soil Biology and Biochemistry 19, 25-30.

Bassinot, F.C., Beaufort, L., Vincent, E., Labeyrie, L.D., Rostek, F., Müller, P. J., Quidelleur, X. and Lancelot, Y. 1994. Coarse fraction fluctuations in pelagic carbonate sediments from the tropical Indian Ocean: a 1500-kyr record of carbonate dissolution. Paleoceanography 9, 579-600.

Beaufort, L. 1996: Dynamics of the monsoon in the equatorial Indian Ocean over the last 260,000 years. Quaternary International 31, 13-18.

Blasco, F. 1971: Montagnes du sud de l'Inde : forêts, savanes, écologie. Pondicherry, India: Institut français de Pondichéry, Travaux de la section scientifique et technique, $\mathrm{n}^{\circ} 10$.

Boudot, J.-P., Bel Hadj, B. A. and Chone, T. 1986: Carbon mineralization in andisols and aluminium-rich highland soils. Soil Biology and Biochemistry 18, 457-61.

Boutton, T. W., Archer, S. R., Midwood, A. J., Zitzer, S. F. and Bol, R. 1998: $\delta^{13}$ C values of soil organic carbon and their use in documenting vegetation change in a subtropical savanna ecosystem. Geoderma 82, 541.

Bowman, D. M. J. S. and Cook, G. D. 2002: Can stable carbon isotopes $\left(\delta^{13} C\right)$ in soil carbon be used to describe the dynamics of Eucalyptus savanna-rainforest boundaries in the Australian monsoon tropics? Austral Ecology 27, 94-102.

Bowman, D. M. J. S., Cook, G. D. and Zoppi, U. 2004: Holocene boundary dynamics of a northern Australian monsoon rainforest patch inferred from isotopic analysis of carbon, $\left({ }^{14} \mathrm{C}\right.$ and $\left.\delta^{13} \mathrm{C}\right)$ and nitrogen $\left(\delta^{15} \mathrm{~N}\right)$ in soil organic matter. Austral Ecology 29, 605-612.

Caner, L., Bourgeon, G., Toutain, F. and Herbillon, A.-J. 2000: Characteristics of non-allophanic Andisols derived from low-activity clay regoliths in the Nilgiri Hills (Southern India). European Journal of Soil Science 51, 553-63.

Caner, L. and Bourgeon, G. 2001: Andisols of the Nilgiri highlands: new insight into their classification, age and genesis. In Gunnell, Y. and Radhakrishna, B. P. editors, Sahyadri, the Great Escarpment of the Indian Subcontinent. Patterns of Landscape Development in the Western Ghats. Bangalore: Geological Society of India, Memoir 47, 905-18.

Caner, L., Toutain, F., Bourgeon, G. and Herbillon, A.-J. 2003: Occurrence of sombric-like subsurface A horizons in some andic soils of the Nilgiri Hills (Southern India) and their palaeoecological significance. Geoderma 117, 251-65.

Cayre, O., Beaufort, L. and Vincent, E. 1999: Paleoproductivity in the Equatorial Indian Ocean for the last $260,000 \mathrm{yr}$ : a transfer function based on planktonic foraminifera. Quaternary Science Reviews 18, 839-57. 
Desjardins, T., Carneiro Filho, A., Mariotti, A., Chauvel, A. and Girardin, C. 1996: Changes of the ForestSavanna boundary in the Brazilian Amazonia during the Holocene revealed by stable isotope ratios of soil organic carbon. Oecologia 108, 749-756.

Emeneau, M. B. 1997: Linguistics and Botany in the Nilgiri. In Hockings, P., editor, Blue Mountains Revisited. Cultural Studies on the Nilgiri Hills. New Delhi: Oxford University Press, 74-105.

Fairhead, J. and Leach, M. 1998: Reframing Deforestation. Global Analysis and Local Realities: Studies in West Africa, London: Routledge.

Farrera, I, Harrison, S. P., Prentice, I. C., Ramstein, G., Guiot, J., Bartlein, P. J., Bonnefille, R., Bush, M., Cramer, W., von Grafenstein, U., Holmgren, K., Hooghiemstra, H., Hope, G., Jolly, D., Lauritzen, S. E., Ono, Y., Pinot, S., Stute, M. and Yu, G. 1999: Tropical climates at the last glacial maximum: a new synthesis of terrestrial palaeoclimate data. I. Vegetation, lake levels and geochemistry. Climate Dynamics 15, 823-56.

Folke, S. 1966: Evolution of plantations, migration and population growth in the Nilgiris and Coorg (South India). Geografisk Tidsskrift 65, 198-239.

Francis, W. 1908: The Nilgiris (Madras District Gazetteers). Delhi, Madras: Asian Educational Services, 1994 Reprint.

Freitas, H. A., Pessenda, L. C. R., Aravena, R., Gouveia, S. E. M., Ribeiro, A. S. and Boulet, R. 2001: Late Quaternary vegetation dynamics in the southern Amazon basin inferred from carbon isotopes in soil organic matter. Quaternary Research 55, 39-46.

Gadgil, S. 2003: The Indian monsoon and its variability. Annual Review of Earth and Planetary Science 31, 429-467.

Guillet, B., Faivre, P., Mariotti, A. and Khobzi, J. 1988: The ${ }^{14} \mathrm{C}$ dates and ${ }^{13} \mathrm{C} /{ }^{12} \mathrm{C}$ ratios of soil organic matter as a mean of studying the past vegetation in intertropical regions: examples from Colombia (south America). Palaeogeography, Palaeoclimatology, Palaeoecology 65, 51-58.

Gunnell, Y. 1998: The interaction between geological structure and global tectonics in multistoreyed landscape development: a denudation chronology of the South Indian shield. Basin Research 10, 281-310.

Gunnell, Y. 2000: The characterization of steady state in earth surface systems: findings from the gradient modelling of an Indian climosequence. Geomorphology 35, 11-20.

Gunnell, Y. and Bourgeon, G. 1997: Soils and climatic geomorphology on the Karnataka Plateau, peninsular India. Catena 29, 239-62.

Gunnell, Y. and Louchet, A. 2000: The influence of rock hardness and divergent weathering an the interpretation of apatite fission-track denudation rates. Evidence from charnockites in South India and Sri Lanka. Zeitschrift fur Geomorphologie 44, 33-57. 
Gunnell, Y., Anupama, K., and Sultan, B. in press: History of the South Indian runoff-harvesting civilization and northeast monsoon variability during the last two thousand years. The Holocene.

Gupta, H. P. and Prasad, K. 1985: The vegetational development during 30,000 years B.P. at Colgrain, Ootacamund, Nilgiris, S. India. Journal of Palynology 21, 174-87.

Legris, P. 1963: La végétation de l'Inde. Ecologie et flore. Pondicherry, India: Institut Français de Pondichéry, Travaux de la Section Scientifique et Technique, 6 .

Mariotti, A. and Peterschmitt, E. 1994: Forest savanna ecotone dynamics in India as revealed by carbon isotope ratios of soil organic matter. Oecologia $97,475-80$.

Markham, C. R. 1866: Map of the Neelgherries, Koondahs and Wynaad, to illustrate the progress of cinchona cultivation into British India up to July 1866. Royal Geographical Society, London.

Myers, N., Mittermeier, R. A., Mittermeier, C. G., da Fonseca, G. A. B. and Kent, J. 2000: Biodiversity hotspots for conservation priorities. Nature 403, 853-858

Pascal, J.-P. 1988: Wet evergreen forests of the Western Ghats of India. Pondicherry, India: Institut Français de Pondichéry, Travaux de la Section Scientifique et Technique, 20

Pessenda, L. R., Gomes, B. M., Aravena, R., Ribeiro, A. S., Boulet, R., and Gouveia, S. E. M. 1998 : The carbon isotope record in soils along a forest-cerrado ecosystem transect: implications for vegetation changes in the Rondonia state, southwestern Brazilian Amazon region. The Holocene 5, 599-604.

Pessenda, L. C. R., Boulet, R., Aravena, R., Rosolen, V., Gouveia, S. E. M., Ribeiro, A. S. and Lamotte, M. 2001: Origin and dynamics of soil organic matter and vegetation changes during the Holocene in a forestsavanna transition zone, Brazilian Amazon region. The Holocene 11, 250-254.

Poulenard, J. and Herbillon, A.-J. 2000: Sur l'existence de trois catégories d'horizons de référence dans les andosols. Comptes Rendus de l'Académie des Sciences, Série 2, Sciences de la terre et des planètes 331, $651-57$.

Prabhu, C. N., Shankar, R., Anupama, K., Taieb, M., Bonnefille, R., Vidal, L. and Prasad, S. 2004: A 200ka pollen and oxygen-isotopic record from two sediment cores from the eastern Arabian Sea. Palaeogeography, Palaeoclimatology, Palaeoecology 214, 309-21.

Rajagopalan, G., Sukumar, R., Ramesh, R., Pant, R. K. and Rajagopalan, G. 1997: Late quaternary vegetational and climatic changes from tropical peats in southern India - an extended record up to 40,000 years BP. Current Science 73, 60-63.

Rajagopalan, G., Ramesh, R. and Sukumar, R. 1999: Climatic implications of delta ${ }^{13} \mathrm{C}$ and delta ${ }^{18} \mathrm{O}$ ratios from C3 and C4 plants growing in a tropical montane habitat in southern India. Journal of Biosciences 24, 491-98. 
Ramesh, B. R., De Franceschi, D. and Pascal, J.-P. 2002: Forest map of South India, sheet CoimbatoreThrissur. Scale 1: 250,000. Pondicherry, India: Kerala and Tamil Nadu Forest Departments, Kerala Forest Research Institute and French Institute of Pondicherry.

Rostek, F., Ruhland, G., Bassinot, F. C., Müller, P. J., Labeyrie, L.D., Lancelot, Y., and Bard, E. 1993: Reconstructing sea surface temperature and salinity using delta ${ }^{18} \mathrm{O}$ and alkenone records. Nature $364,319-$ 21.

Schwartz, D., de Foresta, H., Mariotti, A., Balesdent J., Massimba, J.-P. and Girardin, C. 1996: Present dynamics of the savanna-forest boundary in the Congolese Mayombe: a pedological, botanical and isotopic $\left({ }^{13} \mathrm{C}\right.$ and $\left.{ }^{14} \mathrm{C}\right)$ study. Oecologia $106,516-524$.

Sehgal, J. L., Natarajan, P., Reddy P. S. A. and Dhanapalan Mori A. 1996: Tamil Nadu Soils. 4 sheets at 1:500,000 scale. National Bureau of Soil Survey and Land Use Planning in co-operation with Department of Agriculture of Tamil Nadu, Bangalore, India.

Sollins, P., Homann, P. and Caldwell, B. A. 1996: Stabilization and destabilization of soil organic matter: mechanisms and controls. Geoderma 74, 65-105.

Sukumar, R., Ramesh, R., Pant, R. K. and Rajagopalan, G. 1993: A delta ${ }^{13} \mathrm{C}$ record of late Quaternary climate change from tropical peats in Southern India. Nature 364, 703-706.

Sukumar, R., Suresh, H. S. and Ramesh, R. 1995: Climate change and its impact on tropical montane ecosystems in southern India. Journal of Biogeography 22, 533-36.

Van Wambeke, A. 1992: Soils of the Tropics. Properties and appraisal. New York. McGraw-Hill.

Von Lengerke, H. J. 1977: The Nilgiris: weather and climate of a mountain area in South India. Wiesbaden: Franz Steiner Verlag.

Wasson, R. J. 1995: The Asian monsoon during the Late Quaternary: a test of orbital forcing and paleoanalogue forecasting. In Wadia, S. Korisettar, R. and Kale, V. S. editors, Quaternary Environments and Geoarchaeology in India. Bangalore: Geological Society of India Memoir 32, 22-35.

Whitmore, T. C. 1986: Mountain rain forests. In Whitmore, T.C., editor, Tropical Rain Forests of the Far East (2nd edition.), Oxford: English Language Book Society and Oxford University Press, 243-59.

Acknowledgements. We thank two anonymous referees who provided helpful comments on the manuscript. 